TITLE:

\title{
TWO NEW FOSSIL DEMOSPONGES FROM WEST ONGUL ISLAND, LUTZOW-HOLM BAY, ANTARCTICA
}

$\operatorname{AUTHOR}(S)$ :

Hoshino, Takaharu

\section{CITATION:}

Hoshino, Takaharu. TWO NEW FOSSIL DEMOSPONGES FROM WEST ONGUL ISLAND, LUTZOW-HOLM BAY, ANTARCTICA. PUBLICATIONS OF THE SETO MARINE BIOLOGICAL LABORATORY 1977, 24(1-3): 43-48

ISSUE DATE:

1977-11-30

URL:

http://hdl.handle.net/2433/175961

RIGHT: 


\title{
TWO NEW FOSSIL DEMOSPONGES FROM WEST ONGUL ISLAND, LÜTZOW-HOLM BAY, ANTARGTICA ${ }^{1)}$
}

\author{
TAKaharu HOSHINO \\ Mukaishima Marine Biological Station, Faculty of Science, Hiroshima University
}

With Text-figures 1-3, Table 1 and Plate I

During biological surveys on West Ongul Island from Jan. 8, to Feb. 4, 1974, a site with numerous exposed fossil animals was discovered. The site is located at the base of a peninsula flanked by two other peninsulas, all on the northern side of West Ongul Island, about $2 \mathrm{~km}$ northwest from the heliport of JARE's Syowa Station. The elevation there is $5-7.5 \mathrm{~m}$ above sea level. In this area are many bare rocks, and at a place of low ground surrounded by such rocks occurs a pond of thaw water. Deposits of fine sand, spicule balls of hexactinellid sponge, shells, serpuloid tubes, and so forth have accumulated in the pond in the order given. The writer found one small demosponge in the alluvial sample collected here and other large demospongian individuals on the east side of the fossil area.

An elevation of $5-7.5 \mathrm{~m}$ above sea level such as in the site where these fossil demosponges were collected represents a middle level in the area where the writer
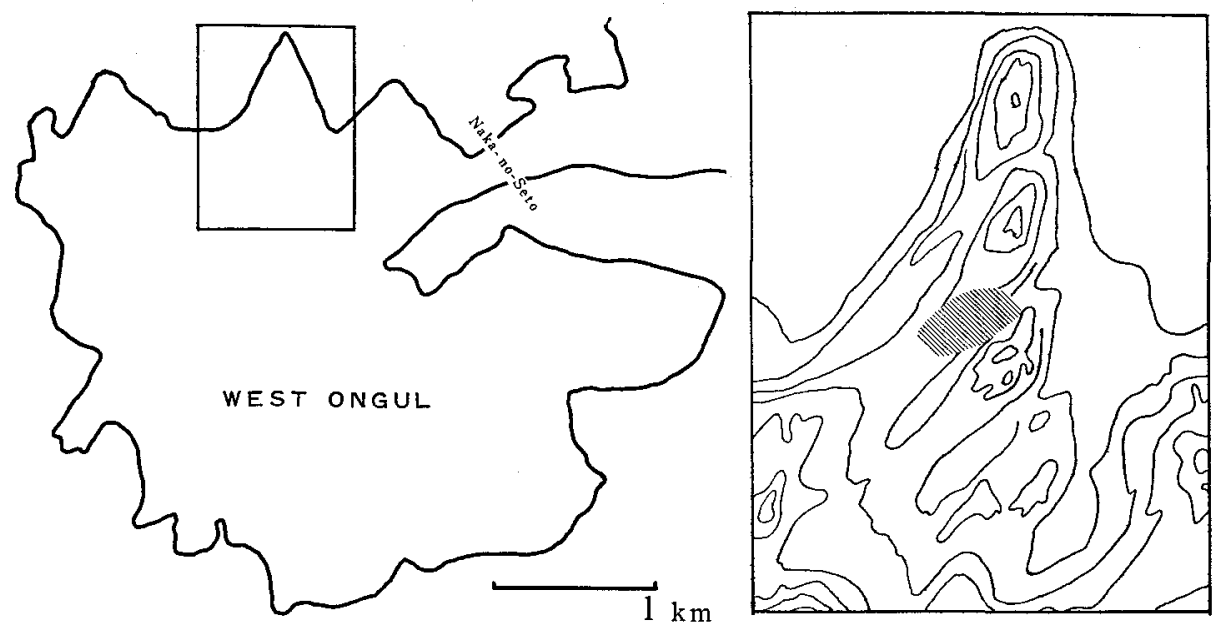

Text-fig. 1. West Ongul Island. The shaded portion indicates area where fossil animals with sponges were found.

1) Contribution from the Mukaishima Marine Biological Station, No. 146.

Publ. Seto Mar. Biol. Lab., XXIV (1/3), 43-48, $1977 . \quad$ (Article 6) 
observed fossils in the Ongul Islands. Fossil shells of Laternula elliptica and Adamussium colbecki, presently common, circumpolar species in the Antarctic area, taken from another site in the study area $0.5-16 \mathrm{~m}$ above sea level, appear to be 3-6,000, and $2-30,000$ years of age as measured by ${ }^{14} \mathrm{C}$ method. It is believed that the times of this section's upheaval do not differ from other locations in this area.

Though these two sponges are fossil in a limited sense, the writer considers it appropriate to treat them as present-day animals for the purpose of classification of the class Demospongia.

\section{Description}

Glass Demospongia

Order Halichondrina

Family Halichondriidae

1. Halichondria longioxea n. sp.

On the east side of the fossil area a few large demospongian individuals were found in the positions they had occupied as living animals. The writer identified this sponge as a new species belonging to the genus Halichondria. It is believed that the specimens observed here had been densely compressed under the weight of snow.

External morphology: Sponge irregularly encrusting, about $50 \mathrm{~cm}$ in diameter, $2-7 \mathrm{~cm}$ in thickness on fine gravels. Surface uneven. Sponge individuals are composed of spicules only since other materials (organic substance) were lost with tide, wave action, or thaw water.

Endosome skeleton: Consists of bread crumbs, as it is described, being formed oxeate spicules only. Exhalent canal 5-6 $\mathrm{mm}$ in diameter running almost perpendi-

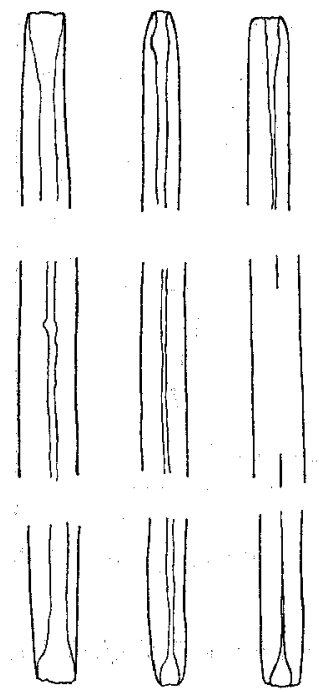

Text-fig. 2. Halichondria longioxea n. sp., Oxea 
cularly to the base.

Spicule: Oxea only, smooth, straight, $0.5-1.5 \mathrm{~cm}$ long, $45-60 \mu$ wide but juvinile spicules are $10 \mu$ wide. Most have a vacant axial thread extending throughout spicule.

Type specimens: WOI-1 (Holotype), Depository: Mukaishima Marine Biological Station, WOI-2 (Paratype), Depository: National Institute of Polar Research.

Remarks: Sponges of the genus Halichondria are generally characterized by simple spiculation of oxea only, tremendous variation in size of spicules, and an endosome-skeleton structure reminiscent of bread crumbs. The specimens observed show the typical characters described above. Sponges of the class Demospongia very rarely possess spicules $1 \mathrm{~cm}$ or over in length except for the members of the order Choristida, which show radiate structure in skeletal morphology.

The spicule length of Halichondria panicea (Pallas), the most cosmopalitan species of the genus Halichondria, is commonly up to $1 \mathrm{~mm}$. In a revision of the antarctic sponges by Koltun (1964), two other members of the genus Halichondria were described. The spicule length of one, Halichondria variabilis Ridley, is up to $0.4 \mathrm{~mm}$ and that of the other, Halichondria hentsheli Koltun, as long as $1.68 \mathrm{~mm}$.

This is the writer's first encounter with a species having spicules $1 \mathrm{~cm}$ or over in length in the genus Halichondria.

\section{Order Poecilosclerina \\ Family Clathriidae}

2. Axociella ongulensis $\mathrm{n}$. sp.

One specimen only was found in the alluvial sample collected from the fossil area.

External morphology: Sponge body digitiform, generally branching, $4 \mathrm{~cm}$ high, the branch about $1 \mathrm{~mm}$ thick, surface minutely bristly. Consistency friable. Color in dry state brown. The skeleton is formed of an axis of longitudinal bundles of spicules and dermal projecting spicules.

Spicule: Macrosclere-Styles of longitudinal axis are smooth, straight, 525576.6 (average) $-835 \mu$ long and $15-18-26 \mu$ wide. Dermal styles are thin, straight, with a few terminal spinules, and 308-417-490 $\mu$ long and 6-7-8 $\mu$ wide. Microsclere-Toxa only, spinulated on both tips from a tenth to a thirteenth of entire length.

Type specimen: WOI-3 (Holotype), Depository: Mukaishima Marine Biological Station.

Remarks: In Koltun (1964), three species in the genus Axociella were distinguished, namely, Axociella nidificata (Kirkpatrick), Axociella flabellata (Topsent), and Axociella rameus Koltun. Comparisons of external morphology and spiculation in these three species and Axociella ongulensis are shown in Table 1.

Axociella ongulensis is, among the three species described above, closest to Axociella nidificata in spiculation but clearly different in external form. Kirkpatrick (1907) 


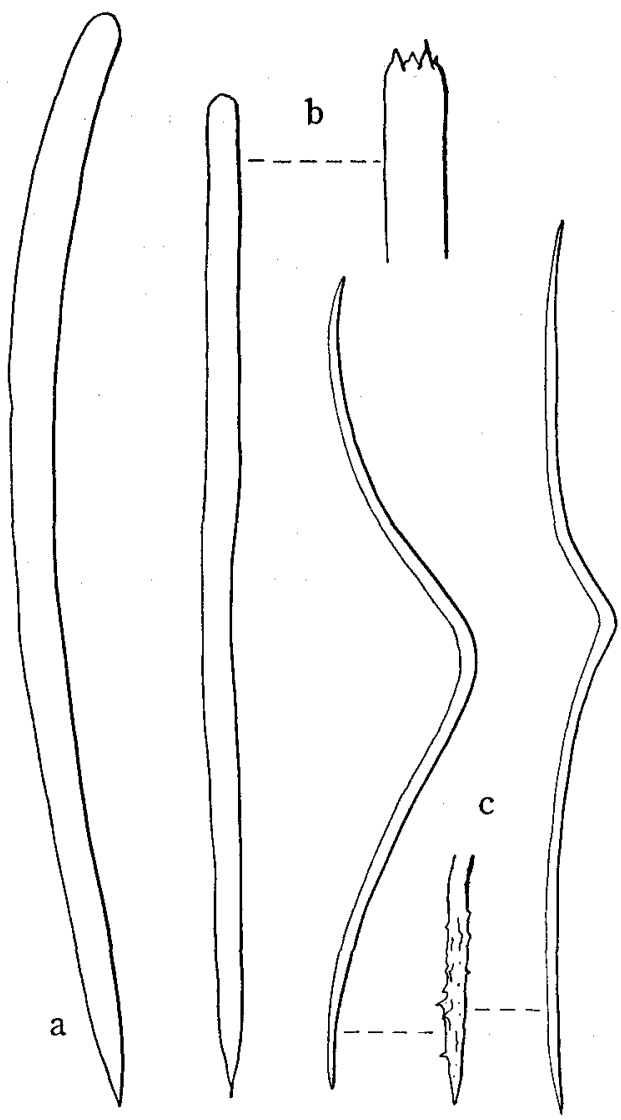

Text-fig. 3. Axociella ongulensis n. sp., a. Style, b. Dermal Style, c. Toxa

Table 1. Comparisons of the four species in the genus Axociella

\begin{tabular}{|c|c|c|c|}
\hline Species & External form & Macrosclere $(\mu)$ & Microsclere $(\mu)$ \\
\hline A. nidificata & globular & $\begin{array}{l}\text { style, } 400-1200 \times 15-60 \\
\text { dermal style, } 300-535 \times 9-10\end{array}$ & toxa, up to 638 \\
\hline A. flabellata & $\begin{array}{l}\text { membranous, } \\
\text { lobate stalked }\end{array}$ & $\begin{array}{l}\text { style, } 540-1300 \times 22-60 \\
\text { dermal style. } 250-770 \times 6-13\end{array}$ & toxa, $100-280$ \\
\hline A. rameus & digitiform & $\begin{array}{l}\text { large style, } 700-1500 \times 21-42 \\
\text { thin style, } 550-870 \times 8-10\end{array}$ & toxa, $190-350$ \\
\hline A. ongulensis & digitiform & $\begin{array}{l}\text { style, } 525-835 \times 15-26 \\
\text { dermal style, } 308-490 \times 6-8\end{array}$ & toxa, up to $650 \times 5$ \\
\hline
\end{tabular}

notes in his original description of Ophilitaspongia (=Axociella) nidificata that its external form is massive, with an inverted pyramidal shape. But these two species, $A$. nidificata and $A$. ongulensis, can be descriminated even by spiculation on the basis of the differences in the size ranges of spicule length and width which are clear on close observation. A. ongulensis resembles $A$. rameus in external form but they are different in spiculation. 


\section{Acknowledgement}

It is a pleasure to record here a debt of gratitude to Professor Akihiko Inaba, Mukaishima Marine Biological Station of Hiroshima University for his kindness in providing constant guidance during the course of the work as well as correcting the paper in manuscript. The writer is grateful also to the members of 15th Japanese Antarctic Research Expedition for their assistance during his investigation. He further wishes to express his thanks to Mr. Reginald B. Gillmor of Maine University for kindly reading the manuscript.

\section{LITERATURE}

Burton, M. 1932. Sponges. Discovery Report 6: 237-392.

1938. Non-calcareous sponges. Sci. Rep. Aust. Antarctic Exp. Ser. G 9(5): 5-22.

Keller, C. 1889. Die spongien Fauna des Rothen Meeres. Zeit. Wiss. Zool. 48: 311-405.

Kirkpatrick, R. 1907. Preliminary report on the Monaxonellida of the National Antarctic Expedition. Ann. Mag. Nat. Hist. Ser. 7 4(2): 271-291.

Koltun, V.M. 1964. Sponges of the Antarctic, 1 Tetraxonida and Cornacuspongida. Issled. fauny morei. 2(10): 6-116.

Laubenfels, M.W. de 1936. A discussion of the sponge fauna of the Dry Tortugas in particular and the West Indies in general, with material for a revision of the Families and Orders of the Porifera. Carnegie Inst. Wash. Pub. 467: 1-225.

Tanita, S. 1959. Sponges, Biological Results of Japanese Antarctic Research Expedition 1. Special Publ. from the Seto Mar. Biol. Lab. pp. 8. 
T. Hoshino

\section{EXPLANATION OF PLATE I}

Figs. 1 \& 2. Halichondria longioxea n. sp., 1. entire animal in nature (camera cap: 5 cm) 2. Holotype (WOI-1)

Fig. 3. Axociella ongulensis n. sp. entire animal, $4 \mathrm{~cm}$ high 
Publ. Seto Mar. Biol. Lab., XXIV (1/3), 1977.

PLATE I
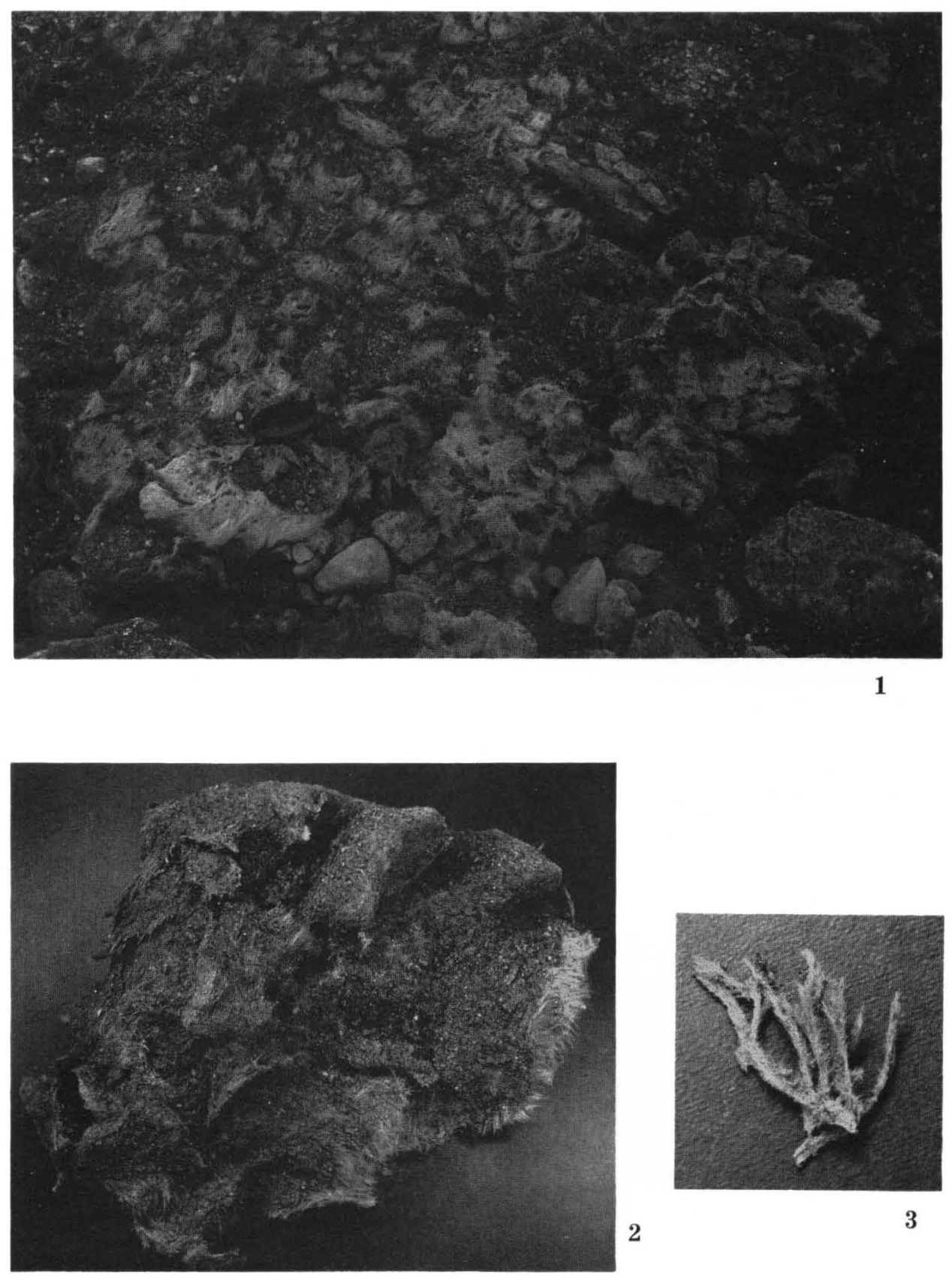

2

T. Hoshino: Two New Fossil Demosponges from Antarctica 